\title{
Integrating Key Insights of Sociological Risk Theory into the Ecosystem Services Framework
}

\author{
Sophie Peter(1)
}

Senckenberg Biodiversity and Climate Research Centre (SBiK-F), 60325 Frankfurt am Main, Germany; sophie.peter@senckenberg.de

Received: 27 May 2020; Accepted: 5 August 2020; Published: 10 August 2020

\begin{abstract}
Environmental risks give urgency to the need to understand the society-nature relationship. While the ecosystem services (ES) framework allows analysis of interrelationships between biophysical supply and human demand for natural resources, further research is needed to understand what drives societal demand for ES. Here, I explore how incorporation of the key sociological theories of risk (systems theory, 'world risk society', and cultural theory of risk) can advance this understanding. By examining these theories, the following key insights were identified: (1) A deeper understanding of societal structures and risk perception helps to understand culturally driven patterns of ES demand; (2) sociological ES research must use inter- and transdisciplinary methods to understand the drivers of ES demand and risk perception. It must also link this understanding to the natural sciences' knowledge of the drivers of ES supply if it is to identify new instruments of environmental governance; (3) while anthropocentric in character, the ES framework, especially one that is modified by the concept of risk, enables society to reflect on its role as a proactive part of a social-ecological system, rather than a passive victim of nature's whims. This change in perspective may prove to be a key step in achieving sustainable development.
\end{abstract}

Keywords: boundary concept; ecosystem services; global biodiversity loss; socio-cultural dynamics; sociological theory of risk; risk of loss

\section{Introduction}

In 1962, Rachel Carson highlighted the destruction of nature and its consequences, and [1] ten years later, the Club of Rome published their influential report on the limits of economic and population growth [2]. Following this, Gretchen Daily published a highly influential article on the ecosystem services (ES) framework in 1997 [3]. It is argued that this concept bridges the eco-centric concept of nature conservation and the more anthropocentric view of a mutual interaction between society and nature [4]. Since then, a series of definitions and classification systems as well as several related science communication strategies were developed [5]. Of these, the Millennium Ecosystem Assessment (MA) set a milestone in the field by defining ES as "the benefits people obtain from ecosystems" [6] (p. V), and the Common International Classification of Ecosystem Services (CICES) split ES into provisioning, regulating and maintenance, and cultural services [7]. Over time, the concept has also moved from the academic to the public sphere via global initiatives, such as the Intergovernmental Science-Policy Platform on Biodiversity and Ecosystem Services (IPBES), which seek to create communication platforms between different groups of societal actors [8]. These initiatives aim to communicate scientific findings, whilst also creating a feeling of societal responsibility to actively shape the future and reduce risks [9].

Retrospectively, it is clear that such science-policy interfaces do not arise from a void. Rather, the necessity for them was preceded by a social process that aimed to manage global environmental risks, such as biodiversity loss. Given this background, it is perhaps surprising that while risk is sometimes considered by ES researchers [10-13], the focus has been on 'real' objective risks (e.g., how 
these risks could influence the ES supply). The subjective perception of risks by society, and how these shape ES demand and use, has received little attention so far and lacks a standardized theoretical framework. In contrast, within sociology, questions of how and why a society recognizes and assesses risks have been studied for decades. Several risk theories have emerged in this research field. In 1986, Ulrich Beck presented the concept of a 'risk society' [14] in which human-made but largely unforeseen risks emerge from technological developments with unintended side effects, the nuclear catastrophe of Chernobyl being a case in point. He elaborated this idea in his theory of a 'world risk society' that has broken away from traditional lifestyles and is enlightened about the negative effects of industrialization. Examples of such risks are those of greenhouse gas emissions and global warming, which are now acknowledged as a global risk by much of the global society. However, how risks are perceived and analyzed differs between academic disciplines [15]: Natural scientists, and those in the ES field, have focused on 'real' risks with measurable and objective consequences, such as deforestation, land degradation, and the impact of these on vital ES, such as carbon storage [16,17]. However, there is often a discrepancy between real and perceived risks in society. While biodiversity loss represents a 'real' and scientifically measurable risk to stakeholders who demand and use ES (e.g., $[18,19])$, these stakeholders may not be aware of the magnitude of this risk. Therefore, the natural science approach to measuring this risk provides limited information about how society perceives risks, and does not provide an understanding of how to transfer knowledge about risks or how to manage them. According to the sociologist Niklas Luhmann [20], the natural science perspective is a first-order observation (e.g., the calculation of risk likelihood and impact employed by the World Economic Forum's Global Risk Report [21]). In contrast, what is termed the second-order observation focuses on how the social perception of risks modifies the first-order observation. From this point of view, risks are shaped by "expectations" and "knowledge and experiences of the past" [22] (p. 4). Additionally, at this second level, "... what one considers as risky depends not just on knowledge but on sociocultural and individual values as well" [22] (p. 4). This social modification of risk can result in the under- or overestimation of risks by individuals and society [23]. Here, I argue that while there have been many studies on objective risks [10-12,24], the concept of socio-culturally shaped risk perception in society and how this shapes ES demand and use has not been properly explored [13]. Consequently, I argue that employing the cultural theory of risk has the potential to provide important theoretical and empirical insights [25].

In this paper, I reflect on the ES framework from the perspective of the sociological theory of risk. I argue that environmental impacts like biodiversity loss, climate change, or land degradation are global risks that could limit ES supply and, in turn, influence human ES demand via a feedback loop. First, the paper reviews the ES framework via a critical reflection on multi- and interdisciplinary ES approaches. Second, the three main theories of sociological risk research are explored in order to identify how a consideration of sociological risk can provide additional insights within ES research. In the final section, an integration of the ES and sociological risk concepts is presented and discussed, with a focus on how the incorporation of social risk concepts into ES research can improve our understanding of ES risk perception, the drivers of ES demand, and the sustainable management of ES.

\section{The Ecosystem Services Framework}

To better understand how sociological risk theories can be integrated into the ecosystem services (ES) discourse, I first examine the multi- and interdisciplinary approaches taken within the ES field (Figure 1). Notions of ES differ according to disciplinary perspectives [26-29]. Natural science disciplines look at the flow of material benefits from a realist perspective, in which ES are rationally, physically, and objectively measured $[17,30]$. This worldview marks one end of an spectrum, which runs to a social-based perspective, where the focus is on culturally driven demand for nature's benefits [17,31-33]. In between, there is a range of interdisciplinary approaches that attempt to bridge these perspectives. For the purpose of this article, I heuristically classify previous ES approaches into the following categories, with a strong focus on the social-ecological approach: 

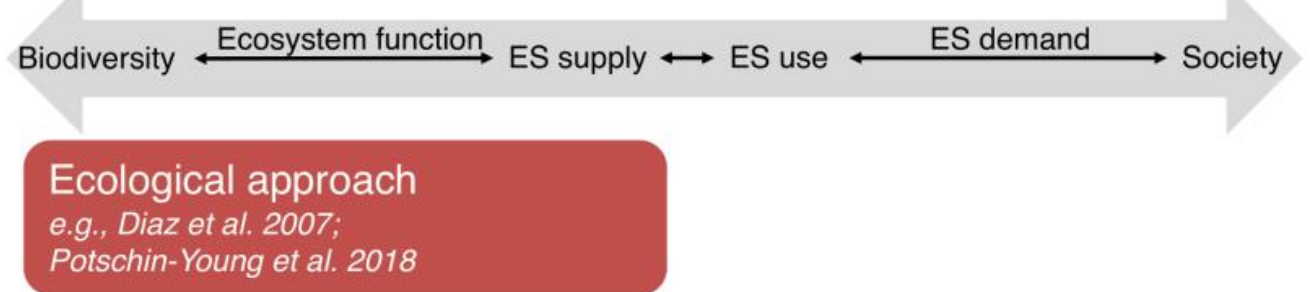

Economic approach

e.g., Costanza, 1997;

TEEB, 2018

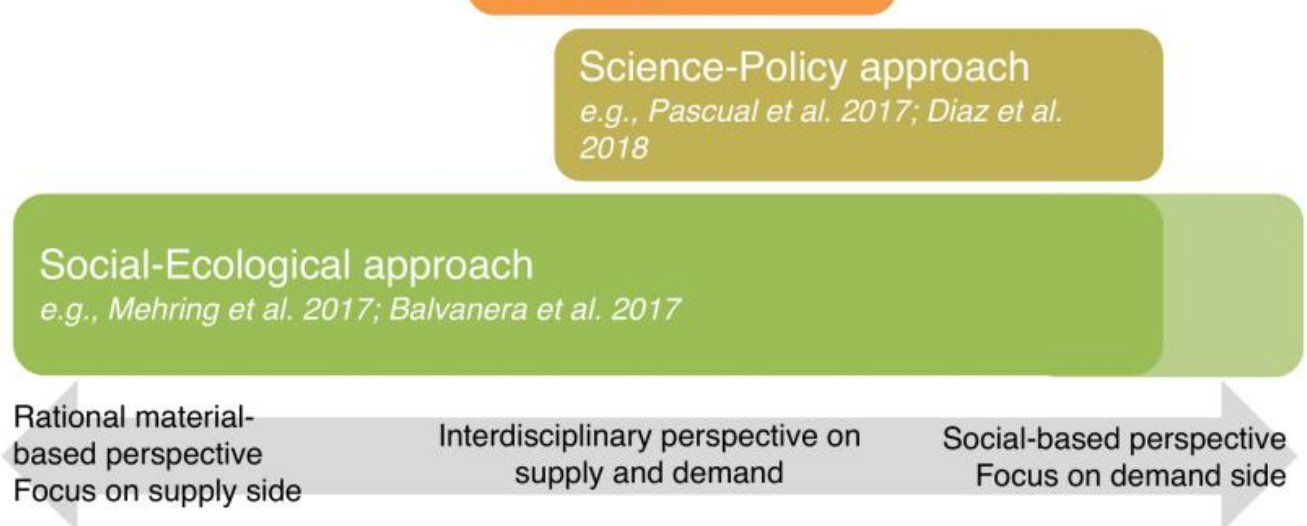

Figure 1. Multidisciplinary approaches of the ecosystem services framework and their focuses within the nature-society relationship (source: Adapted from Felipe-Lucia et al. [27]). The top arrow shows the cascade model [34], the bottom arrow the perspective and focus of the different approaches. The potential extension of the social-ecological approach is indicated by different shades of green.

The ecological approach is applied by natural scientists interested in the flow from biodiversity to ecosystem functions and, subsequently, to ES (e.g., [35]). Humans are represented only as passive recipients of ES, e.g., in the well-known cascade model in which ecosystem functions flow to services and then to human benefits [34,36-38]. 'Real' ecological risks are present in such a model in the form of global change drivers that reduce the potential supply and, consequently, the material supply of ES [39-41].

The economic approach is also based on the cascade model, but with a focus on integrating economic theory [42-44]. Here, a common language between science, politics, and economics was found by assigning monetary values to ES, thus allowing the value of ES (e.g., in different contexts) to be compared in common and standardized units [44]. This approach has been criticized because of its "anthropocentric and economic impetus" [45] (p. 2), its failure to value non-material benefits, and its lack of acknowledgement of the importance of the social context in shaping values [46,47]. Nevertheless, a large research community performs economic assessments of ES, and the approach is applied globally to demonstrate the value of natural resources [31].

The science-policy approach, currently represented by the IPBES on a global scale, calls for a new perspective on the ES debate, which considers "Nature's contribution to people" (NCP) [48]. NCP is defined as: "All the contributions, both positive and negative, of living nature (diversity of organisms, ecosystems, and their associated ecological and evolutionary processes) to people's quality of life" [48] (p. 270). Interdisciplinary scientific results are discussed with non-scientific stakeholders to compile an assessment that has global political consensus [49]. This active exchange aims to close knowledge gaps and potentially lead to political commitment and action [50]. The transdisciplinary approach plays an essential role in enabling this because it highlights the importance of culture, as well as indigenous and local knowledge [8]. 
A similar perspective to the science-policy approach, but with differences in methods of valuation and scope, is found in the interdisciplinary social-ecological approach [51-58]. Cumming [59] describes a social-ecological system (SES) as "an integrated system of people and nature in which feedbacks occur between human and biophysical system elements" (p. 4). Among the users of this approach is a small but steadily growing research community that focuses on understanding the socio-culturally driven demand for ES with the ambition of linking ecological and social approaches [31,33,60-64]. As shown in Figure 1, this approach can cover the entire range of the cascade model. In an SES, human demand for ES is influenced by social and economic conditions of groups and individuals [33,65-68]. Within SES research, scientific interest focuses on temporal and spatial dynamics of current ES supply, demand, and use, as well as their interrelationships $[24,60,62-64,69,70]$. The influence of humans on the ecosystem, e.g., through land use and climate change, is also accounted for, in contrast to the cascade model, where this feedback loop receives little attention [11,31,60,71,72]. Different 'types of demand' are also sometimes distinguished, and these include (1) risk reduction (e.g., by protecting regulating services); (2) preferences and values of ES; (3) direct use; or (4) consumption of goods and services [64]. Here, social risk concepts begin to play a role. SES researchers have investigated aspects of risk perception, but these studies lack a theoretical basis and a deeper analysis of socio-cultural dynamics $[10,11,13]$. Due to their holistic nature, the findings of SES research can potentially inform collective action [73] and management strategies, e.g., by identifying ways of reducing trade-offs between ES and conflicts between stakeholders, and by educating and empowering civil society with an appreciation of multiple perceptions and demands, as demonstrated by the Program on Ecosystem Change and Society (PECS) [33,63,64,74].

With this systematic consideration, it becomes clear that the various approaches pursue different objectives. Although there has been a shift towards an SES approach to studying ES, studies that consider the whole range from both the biophysical and socio-cultural perspectives are still rare $[60,63,64,70,74]$. Therefore, Figure 1 indicates the potential extension of the SES approach. While some ES researchers consider risk perception, this is often implicit, and so there is a lack of investigation into which social-ecological structures and processes drive patterns of ES demand. Furthermore, there is little understanding of how the socio-culturally driven perception of environmental risks shapes ES demand. Next, I will argue that this gap can be addressed by taking into consideration the sociological theory of risk.

\section{Ecosystem Services under the Light of Risks of Loss}

The previous section showed that the variety of the ES approaches is driven by the need to tailor the ES framework to meet the requirements of different users and audiences. The SES approach combines both nature and society, thus making it a way to scientifically approach the question of how society deals with and is affected by environmental impacts and risks [9,23], and whether the behavioral response to risk changes their ES demand. This shared focus on both nature and society means that several approaches in sociological risk theory can be integrated with this ES approach. Renn, Schweizer, Dreyer, and Klinke [9] and Zinn [75-77] provide an overview of risk approaches. Renn et al. [9] distinguishes between technical/natural scientific concepts of 'real' risks and social science risk analysis. In contrast, in this paper, I focus on how social science approaches treat risk in order to understand social structures and processes, as well as individual actors and their risk perceptions and assessment.

To classify and provide an overview of risk approaches, Renn et al. [9] (p. 46) created a matrix. On the first axis of this matrix, they distinguish between realist and constructivist approaches. Realist approaches claim that an empirical research approach to collecting data from the natural, objective world is possible. In contrast, constructivist approaches assume that a worldview is socio-culturally constructed, meaning that nature cannot be represented without acknowledging the influence of societal norms and values [9]. The second axis distinguishes between system- and action-theoretical approaches, i.e., with the focus on the structure or action of and within the social system. Sociological 
risk theories can be categorized within this matrix, which aids an understanding of their orientation and potential for ES research (see Figure 2). Although ES approaches take realist, as well as structural and individual, perspectives, a consideration of the ES framework from the constructivist level has only been touched upon by the SES approach. Due to its interdisciplinary character and focus on societal perspectives and norms, the social-ecological approach has the potential to combine the realist and constructivist approaches, thus providing a new perspective on ES supply and demand.

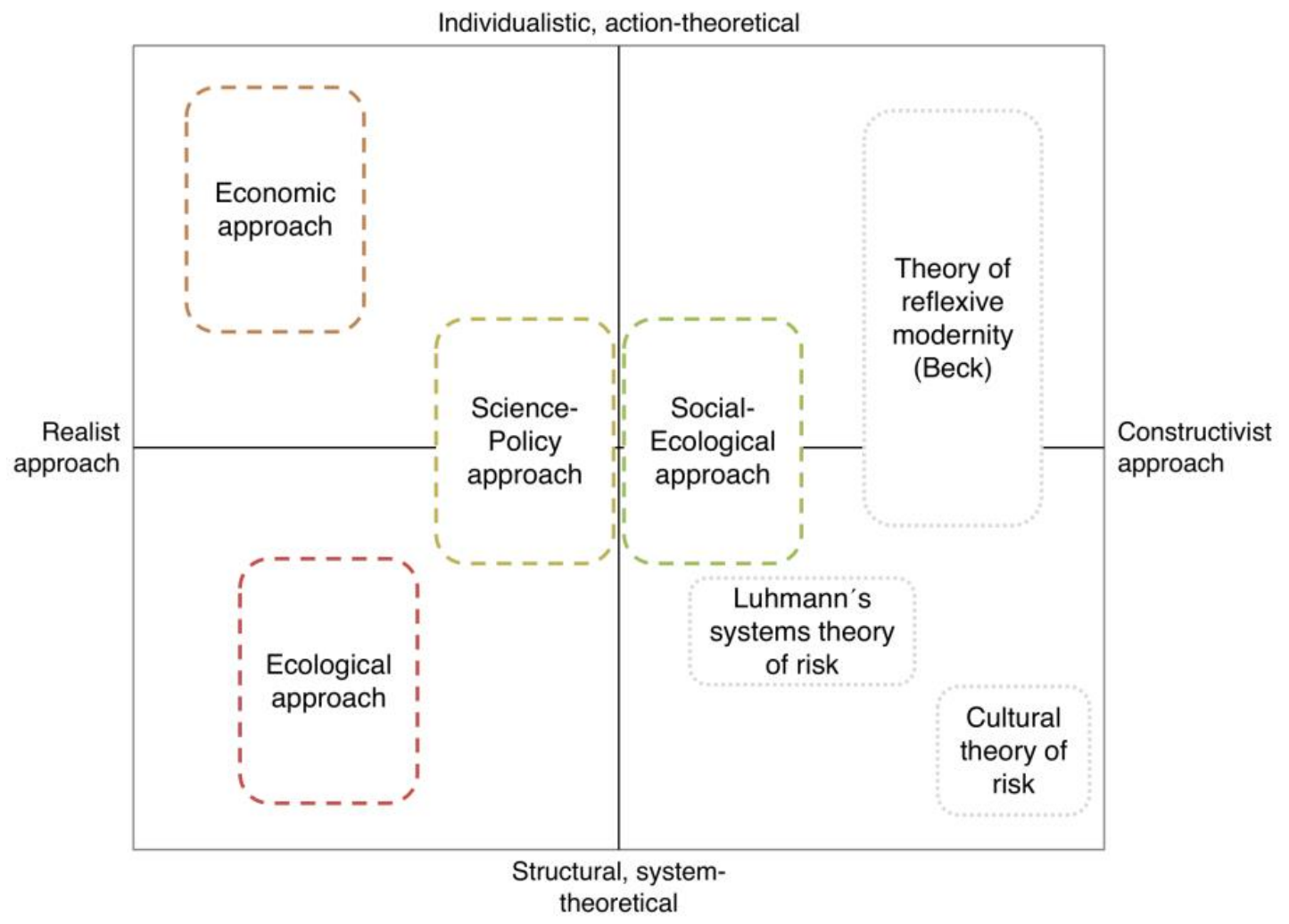

Figure 2. Localization of social science risk approaches and approaches of the ES framework (source: Translated and adapted from [9] (p. 46).

\subsection{Environmental Risks from a System-Theoretical Perspective}

Luhmann's radical constructivist metatheory describes society as consisting of self-organizing social subsystems that are functionally differentiated (e.g., science, economy, religion, and politics) [78]. These social subsystems initially operate within themselves, meaning they are operationally closed. They can only process information based on their own 'code', 'program', 'medium', and 'function', which create an identity for the social subsystem [79] (e.g., the subsystem of science follows the code of 'true/untrue', the program is 'research', the medium 'scientific findings', and the function 'production of new findings', see Figure 3). Each social subsystem has its own code, and no social subsystem uses the code of another social subsystem (e.g., an ES scientist generates new and truthful knowledge about the society-nature relationship, while businesses would operate on a medium of financial profit). Social subsystems are also structurally coupled $[80,81]$. This is done through communication within the boundaries of the social system. All this refers exclusively to the social system, meaning nature is part of an undefined environment surrounding the social system (see Figure 3). In this theoretical framework, it is not possible for society to communicate with nature-a central point in Luhmann's book 'Ecological Communication' [20,79]. 


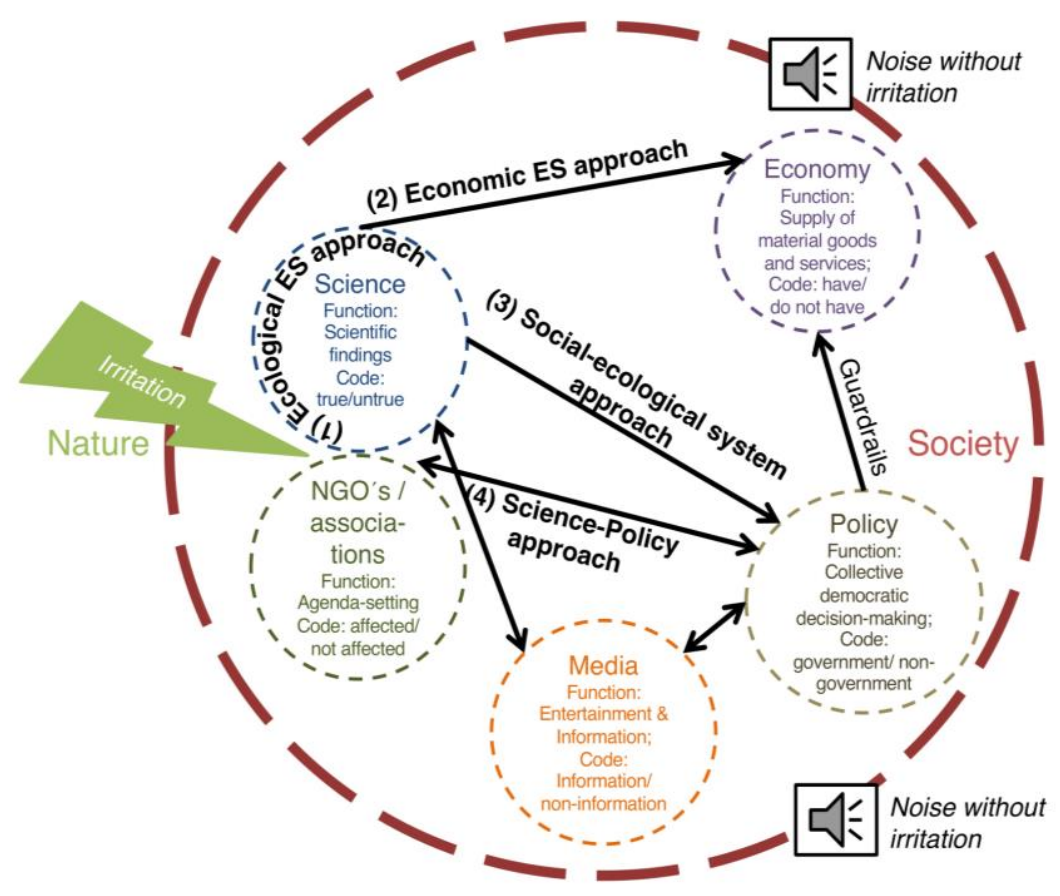

Figure 3. An attempt to visualize the development of the ecosystem services framework and its various approaches (1-4) from the perspective of Luhmann's systems theory. For simplicity, only a subset of social subsystems and linkages between components of the social-ecological system are shown (source: Adapted by $[79,82,83]$ (p. 176)).

The lens of systems theory offers new perspectives on the development of the ES framework and also allows the ES framework to be rethought conceptually. The previous section discussed why the ES framework and its various approaches are needed. Here, I address the issue of how the subsystem of science became aware that the ES framework was needed. Luhmann coined the term 'resonance' to describe the sensitivity of social subsystems to changes in society and nature, what he termed 'external irritations' [82]. In this sense, an awareness of biodiversity loss and its impact on ecosystem functions and services has led to irritation and resonance in the subsystem of science (see Figure 3). Science pursues two tasks as a social subsystem. First, scientists want to contribute to a scientific discourse. Here, it seems that there is a high level of agreement about the urgency of global environmental risks $[84,85]$. The disciplines in science thus irritate each other, and new perspectives, like the aforementioned ES approaches, arise (see Figure 1). Second, science has a responsibility to society and tries to irritate other subsystems to engage in discourse over environmental risks. Thus, science can transform real risks, termed 'dangers' by Luhmann, into tangible societal risks [86], which can be communicated to society [87-89]. From this perspective, risks are "communicated decisions" [15] (p. 173); e.g., in the case of land degradation, the scientific finding that the relationship between society and nature is disrupted. Therefore, the ES framework can be understood as a science program that communicates about the exchange between nature and society [79]. In other words, the ES framework offers a second-order, semi-objective observation of the society-nature relationship [20,82]. Thinking of ES research within this model highlights the social responsibility of ES research, but also shows why there was a need for different ES approaches, because different subsystems need different kinds of irritations.

In Luhmann's understanding of a social system, even if the scientific subsystem has gained knowledge, it does not mean that other social subsystems, like politics or the economy, also recognize this knowledge. Therefore, ES science developed the economic ES approach based on the medium of the economic subsystem (money) as a means of communication [5,47]. For example, biodiversity losses are communicated as representing a lack of profits or payments [82]. This has two objectives: 
(1) The communication about the limited supply of natural resources in economic terms; (2) to transfer the goal of nature conservation into the economic system by demonstrating that it is necessary for economic success $[20,82,90]$. The economy was irritated by this scientific knowledge and is, of course, interested in preserving its own operatively closed economic system [91]. However, Kühne judged the dominance of the economic code, and therefore also the economic ES approach, as a threat to the other social subsystems [82]. The focus on the economic functional system shows the limited perspective and also the limited applicability of the economic ES approach (e.g., as politics follow the medium of 'power', not 'money') $[23,48,65]$. This opens the question as to which new ES approaches could still be developed to irritate further social subsystems (e.g., to irritate the subsystem of politics with an ES approach centered upon power relations [83]).

Secondly, it is interesting to explore how the system-theoretical perspective can contribute conceptually to ES research. First, it shows the complexity of the modern social system and its subsystems, each with a limited ability to communicate, and with diverse orientations. This must be considered in research into the drivers of ES demand because every social subsystem has a unique perspective on ES demand. For example, farmers make land use decisions based on different priorities from those of scientists or politicians. To avoid land use conflicts, irritations and communication between social subsystems must take place regarding the ES supply-demand relationships of different subsystems $[28,35,92]$. It is possible, however, that social subsystems are not always so strongly irritated by other subsystems that their own dynamics are changed. Luhmann describes this stable state as occurring when they are vague 'noises' of environmental 'dangers', as opposed to the system-internal 'structural drift' that occurs under an irritation $[79,93]$. Analysis using this approach, for example, may explain why knowledge about climate change often fails to lead to behavioral change. Nevertheless, within the ES framework, the perspective on ES demand is always limited, as there is no chance to communicate directly with nature [20]. Luhmann is also aware that nature has little interest in whether or not environmental dangers are communicated, and the environment of a social system can be destroyed [82]. To avoid this scenario, risks of loss, like global biodiversity loss, require societal changes and, therefore, resonance across all social subsystems [20]. Thus, a diversified perspective on the social system is essential within ES research. However, the SES approach is particularly compatible with systems theory, as it already attempts to integrate a complex and diverse view of society. Nevertheless, the representation of the social system in ES research can still be refined to further strengthen these links, e.g., by linking empirical social research, such as participatory social network analysis, to systems theory.

While potentially insightful, Luhmann's theory reaches its limits when explaining whether environmental risks are followed by a behavioral change or not. Luhmann states that human consciousness is a prerequisite for social communication [20], and describes the path from consciousness to communication as difficult. This indicates that it is difficult for some social subsystems to respond to an undefined 'noise' from nature. Therefore, irritation from other social subsystems is required to stimulate awareness and action. Nevertheless, Luhmann concludes by saying that his theory of 'ecological communication' does not necessarily aim to offer solutions, but instead aims to understand the social system [20]. Systems theory provides the framework to do this and emphasizes the limited possibility for communication between social subsystems. Nevertheless, to focus on irritation seems insufficient to understand ES demand and how it is influenced by risk. Different social subsystems have different ES preferences, and this plurality of irritations seems to be impenetrable at the system level due to the complexity of modern society. In contrast, Beck's theory of reflexive modernity [94-96] allows a more mechanistic view of the social system by providing an understanding of how individuals deal with a globalized, complex, and non-transparent world of risks.

\subsection{Ecosystem Services in a World Risk Society}

Luhmann's system-theoretical perspective allows for a better understanding of complex social structures and their challenges. However, it provides little basis for discussion about normative 
aspects or social development (e.g., how socio-cultural properties, like norms and values, drive ES demand). Moreover, as a radical constructivist, he believes that risks do not exist if no one talks about them [79]. In contrast, Beck assumes that risks exist regardless of society's perceptions of them [97]. This conception links radical constructivism to realism with a central point: "The risks are real in the sense that they have real impacts, but the knowledge socially constructed by science and other instances is more or less uncertain" [98] (p. 26). For him, nature and society are "intermeshed" [95] (p. 58). It is therefore valuable if the risk approach is viewed from the action-theoretical perspective in order to provide insights into the ES framework.

In the theory of a reflexive (second) modernity [99], the realization that human activities can lead to global environmental risks represents an 'epochal break' towards a new 'risk society' $[94,97,100]$. He argues that the development of modern society is intrinsically linked to risks and uncertainties [16]. This recognition is further elaborated as a 'world risk society' with the thesis that industrialization started the process of "self-dissolution, self-endangerment, and self-transformation" [95] (p. 163). The "first modernity' was dominated by capitalist thinking [100], as well as "organized irresponsibility" [97] (p. 13). The 'second modernity' is characterized by increasing globalization and "detraditionalization" [101] (p. 129). This societal development towards the decoupling of production and consumption is also discussed by scientists in the ES research field, but without the focus on risks [59,102,103]. In the context of ES supply, globalization generates a geographical and temporal decoupling of behavior and possible risks (e.g., air pollution in another part of the world due to the relocation of production). However, the perception of not being affected by decoupled risks may be deceptive, because "risks of modernization sooner or later strike those who produce or profit from them" [94] (p. 23). Beck describes this boomerang effect very aptly with his often quoted sentence: "Poverty is hierarchical, smog is democratic" [94] (p. 36). Thus, with regard to environmental risks like climate change, air pollution, and biodiversity loss, the focus is on issues such as pan-global externalization and inequality, e.g., the externalized value chain, the economic system with its focus on maximum yield, and/or our consumer behavior. These risks pose several challenges. First, large-scale hazards cannot be limited temporally, spatially, or socially. Second, it is difficult to identify the persons causing the loss with any degree of certainty and to thereby hold them responsible. Finally, it might not be possible to compensate the victims economically [97]. In contrast to Luhmann and his vision of a static and functionally differentiated social system, Beck recognizes the urgency of (global) collaboration and networking [100].

Sociology is divided into different worldviews, with some sociologists neglecting the material dimension of nature, which is typically left to the natural sciences [100]. As described above, Beck moves from radical constructivism to realism, in that risks are real, but knowledge of them is socially constructed. This differentiation is apparent when considering environmental risks, because even if risks are perceived and understood, an appropriate action might not occur (e.g., being aware of the impacts of greenhouse gas emission, but not altering behavior accordingly) [98]. While environmental risk is real and can be measured globally, its consequences are sometimes not yet felt, or people are often unaware of them. For this reason, reflexive science can play an important role by setting the societal agenda and strengthening a sense of responsibility [100]. "In this line of argument, one could claim that risks only "'become risks' due to our (scientific) knowledge" [97] (p. 11). However, other social actors, like media and their reporting, are also important [104]. Additionally, social movements such as Fridays For Future or Extinction Rebellion and science-policy interfaces like IPBES are essential in drawing attention to environmental risks, and they highlight the tension between the freedom and responsibility of social actors within a social system [105].

While Luhmann discusses his theory at the systems level, Beck provides an opportunity to better understand the individual level of ES demand [105,106]. Here, Beck distinguishes between reflexivity and reflection: "On the one hand, reflexivity, understood as the confrontation of modernity with its own results (risk), and on the other hand, reflection, understood as a possible awareness of the 'self-destructive potentials' of the (world) risk society" [97] (p. 15). This makes it clear that although a society can recognize the risks of biodiversity loss, the individual does not have 
to relate this risk to its own actions. The theory focuses on individualization, a pluralization of lifestyles, and institutionalized individualism [99], with the aforementioned detraditionalization leading to a decoupling of old social structures (e.g., social class, religion) $[94,97,100]$. Therefore, Beck also addressed the effects of globalization [107]. The 'cosmopolitan society' has a "global risk consciousness" [96] (p. 62), and increasing the movement and independence of citizens provides a breeding ground for a "cosmopolitan democracy" [97] (p. 5). Scientific and political power should be critically questioned [9], as well as a reassessment of societies' relationships with nature. Beck's theories offer an approach to characterizing society and its development. Trends such as globalization, individualization, and changes to socio-cultural risk perception offer a new perspective on ES demand on the macro- as well as micro-level $[96,104]$. In order to counter risks, global political cooperation is necessary to create risk awareness. Thus, global boundlessness is not only the cause, but might also be the solution to managing future risks [9], e.g., via organizations like the Intergovernmental Panel on Climate Change (IPCC) and IPBES.

Beck's theory of a world risk society is often criticized for not paying enough attention to the societal contextualization of risk perception $[15,98,108,109]$. In contrast, Mary Douglas and Aaron Wildavsky offer the radical constructivist approach of the cultural theory of risk, which was developed in a time in which the realization of ecological risks through self-responsible action occurred $[97,110]$.

\subsection{Context Matters: Socio-Cultural Dynamics and Risk}

In the 1980s, scientists of the sociological risk research field devoted themselves to the question of how socio-cultural dynamics influence risk perceptions [111]. This led to the constructivist cultural theory of risk, which has subsequently been much discussed and further developed [109,110,112-118]. Overall, the cultural theory of risk aims to demonstrate that "risks are socially constructed and caused by structural rather than individual forces" [119] (p. 62). Accordingly, it highlights that it is not only important to investigate how people perceive risks on an individual level, but also how this perception is influenced by their societal environment and their culture $[117,120]$. This context-specific orientation influences what might be possible environmental management strategies, according to Price et al. [121], e.g., how much individuals trust political institutions to minimize a risk would determine whether individuals or governments should be targeted for behavioral change. This shows the focus on the individual level, which is often missed in Beck's theory $[15,108,109]$.

In terms of the ES framework, the cultural theory of risk supports the SES research approach and highlights the need to account for the spatial and temporal socio-cultural dimensions when analyzing ES demand. Such consideration helps to understand ES demand patterns and how risks influence possible behavioral changes. Second, it can be said that not only ES demand, but the ES framework itself is socio-culturally driven. For example, the economic approach clearly aims to show politicians and other powerful stakeholders how much a certain ES is worth, thus making their environmentally damaging actions and policies culpable and demonstrating the risk of externalizing ES from the economic system [122]. Thus, the ES framework aims "to uphold judgments of appropriateness and hence to reproduce a particular social order" [117] (p. 74). This, in turn, leads to social judgment and changes to the social order. For example, the fact that the IPBES's 'Nature's contribution to people' (NCP) concept integrates socio-cultural aspects into ES assessments may alter the judgment and valuation of nature. The different ES approaches can therefore be seen as a cultural debate between different worldviews, e.g., when distinguishing between ES and NCP [48] or between economic and diversified valuations of nature [8].

The cultural theory of risk recognizes that people perceive risk differently [114], and groups these perspectives into 'cultural prototypes', thus enabling a focus on cultural group conditions within a modern industrial society. These theoretical considerations aim to help understand risk awareness and valuation, especially that of environmental risks $[9,75,99,119,123]$. These prototypes can be represented in the so-called 'Group' and 'Grid' typology [111,112], which consists of two dimensions upon which individuals or communities are placed (Figure 4). Group, on the horizontal axis, defines the degree of 
"collective pressure" and its acceptance [112] (p. 3), while Grid, on the vertical axis, "stand[s] for the extent to which someone accepts and respects a formal system of hierarchy and procedural rules" [119] (p. 62). By combining these two dimensions, one can define four worldviews, or ways of life (Figure 4). In considering this framework, Thompson and Wildavsky concluded that "any community has several cultures, and that each culture defines itself by contrast with others" [in 112] (p. 8). In linking this theory to environmental risks, other scientists $[115,117,124,125]$ have argued that "the four cultural biases are connected to special myths about the functioning of nature" [111] (p. 158). These 'myths of nature' affect risk perception [116].

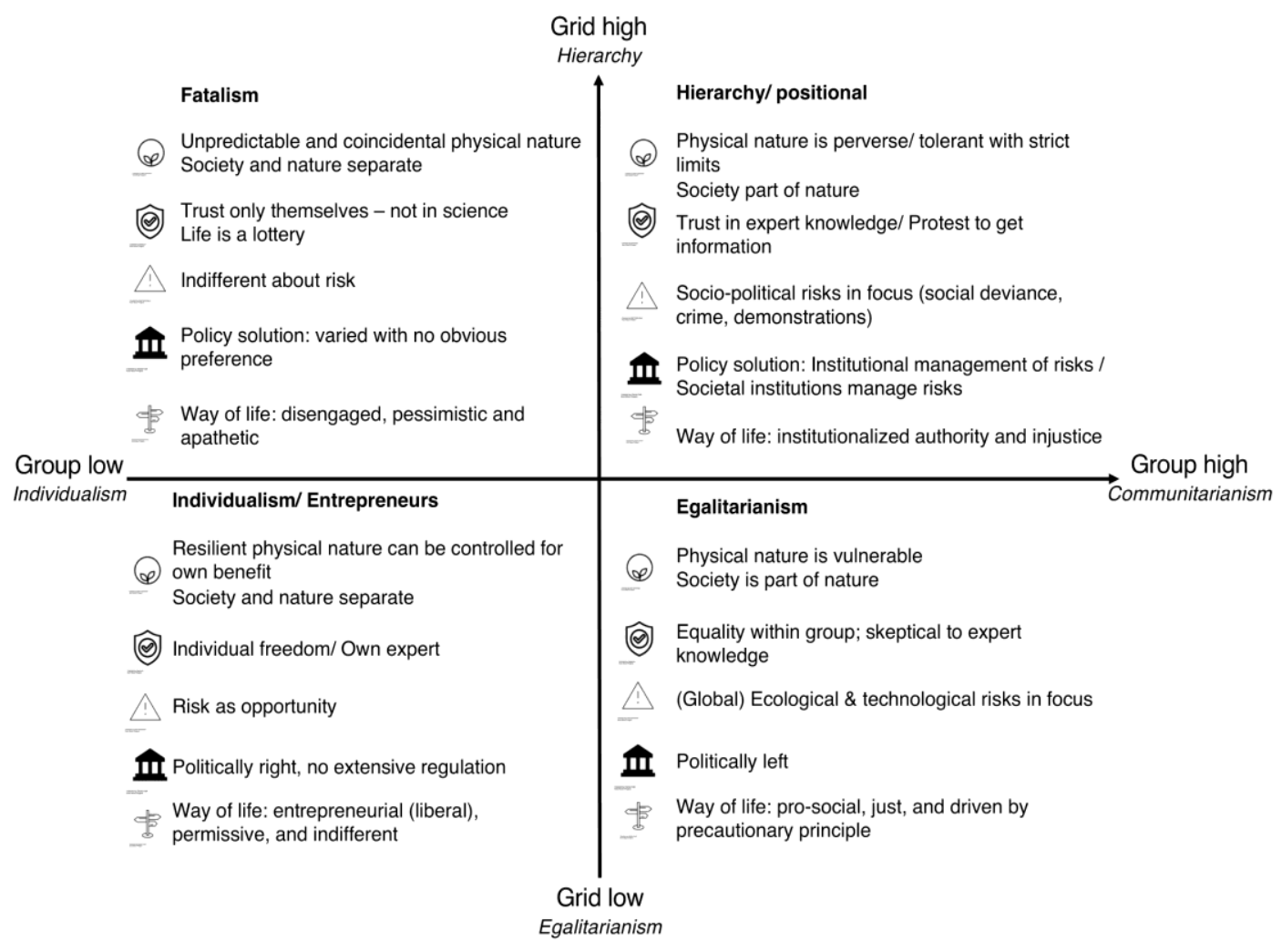

Figure 4. Grid-Group typology and myths of nature that categorize lifestyles and their orientation (derived from [111,115-117,119,121,125-129]). Icon source: thenounproject.com

With regard to the ES framework, it becomes clear that belonging to a culturally biased group shapes one's opinion about the relationship between human and nature, as well as one's views of how nature should be managed. Depending on the type, it is either nobody, individuals, or institutions that are obliged to regulate the ES demand-supply dynamic and its related risks. For example, an individualist sees the economic risks of biodiversity loss or land degradation as the main concerns and considers free-market individual decision-making a solution; hence, they try to develop new business ideas in response to this risk. Besides belonging to a cultural type, knowledge plays a central role in environmental risk perception and judgment [125]. For example, many members of the environmental movement Extinction Rebellion could belong to the egalitarian type, as the movement emerged on the 'border' of society and rebelled against the 'center' $[115,117]$. Nevertheless, an individual's perception of environmental risks and their behavioral response to these risks could differ because "people can handle situations in contradiction of their myth of nature because this relation is mediated by other factors such as the situational constraints" [125] (p. 256), e.g., current prosperity, a crisis situation, or family circumstances.

While cultural theory of risk has had a huge impact upon risk research, it has also endured much criticism. These relate to three aspects: The (1) flexibility of the theory, (2) the focus on the individual, 
and (3) its operationalization. The first criticism questions the Grid-Group typology including whether individuals can move between the types and whether so-called hybrids exist [117]. While Douglas emphasized the statics of the typology, she also emphasized the "multidimensionality" of society and its perception of risk [114] (p. 39). More generally, critics have stated that "people are so different that a general theory is not sufficient" [116] (p. 30). The second criticism is about the focus on the individual and the failure to properly measure their social context [117]. This point is directly related to the problem of operationalization of the theory, e.g., in quantitative analysis [116]. Indeed, the correlation between worldviews and risk perception could not be quantitatively proven in many studies $[111,114,116,130]$.

Some scientists perceive the criticisms as a misinterpretation of Douglas and Wildavsky's original considerations. They understand the theory and typology more as heuristics [114,117]. The lack of quantitative evidence of the existence of the four cultural types and their risk perceptions could also be the proof of the "well-documented gap between environmental knowledge, attitude, and pro-environmental behaviors" [121] (p. 11). Additionally, it can be recognized that, in reality, there is a mix of types that can exist in a single person [121]. Tansey and O'Riordan [117] therefore propose detailed case studies as a methodological approach in order to collect more data describing what determines an individual's Grid-Group type and risk perception. In summary, despite the numerous criticisms, the cultural theory of risk is a significant element of sociological risk research. It makes clear that it is necessary to understand how people perceive environmental risks and that the classification of individuals into cultural types can lead to a better understanding of how groups perceive risk, who they see as responsible, and which measures may be acceptable to them when aiming to create a sustainable ES supply-demand relationship. Table 1 summarizes the main findings and potential contributions of the three sociological risk theories to ES research.

Table 1. Summary of the main findings and contributions of the sociological risk theories to ecosystem services (ES) research.

\begin{tabular}{|c|c|c|c|}
\hline & Systems Theory & $\begin{array}{l}\text { Second Modernity } \\
\text { (World Risk Society) }\end{array}$ & Cultural Theory of Risk \\
\hline Social conception & $\begin{array}{l}\text { Society is described as } \\
\text { consisting of independent } \\
\text { subsystems. } \\
\text { The social-ecological system } \\
\text { (SES) approach shows } \\
\text { similarities, as it allows a } \\
\text { complex and diverse } \\
\text { perspective on society. }\end{array}$ & $\begin{array}{c}\text { Modern society is } \\
\text { characterized by } \\
\text { detraditionalization and } \\
\text { individualization, but also } \\
\text { globalization. }\end{array}$ & $\begin{array}{l}\text { The focus is on the } \\
\text { individual and their } \\
\text { culturally shaped worldview. } \\
\text { Society can be systematized } \\
\text { in a Grid-Group typology. }\end{array}$ \\
\hline $\begin{array}{c}\text { Representation of } \\
\text { nature }\end{array}$ & $\begin{array}{l}\text { Nature is not defined closely; } \\
\text { it is the undefined } \\
\text { environment of the social } \\
\text { system. Subsystems cannot } \\
\text { communicate directly } \\
\text { with nature. }\end{array}$ & $\begin{array}{l}\text { Nature and society are } \\
\text { seen as in connection with } \\
\text { each other. }\end{array}$ & $\begin{array}{l}\text { Human understanding of } \\
\text { nature is systematized in } \\
\text { four 'myths of nature', } \\
\text { who perceive nature } \\
\text { differently. Depending on } \\
\text { the type, one evaluates } \\
\text { nature as part of society, } \\
\text { or separate. }\end{array}$ \\
\hline Risk definition & $\begin{array}{l}\text { There is no risk as long as it is } \\
\text { not communicated. }\end{array}$ & $\begin{array}{l}\text { Risks exist without being } \\
\text { communicated. } \\
\text { Knowledge of risks is } \\
\text { socially constructed. }\end{array}$ & $\begin{array}{l}\text { The perception of risk is } \\
\text { socially constructed. This } \\
\text { shapes individual risk } \\
\text { perception. }\end{array}$ \\
\hline $\begin{array}{l}\text { Core relation to ES } \\
\text { debate within society }\end{array}$ & $\begin{array}{l}\text { Several ES approaches have } \\
\text { created an irritation in the } \\
\text { scientific community and thus } \\
\text { resonance in other social } \\
\text { subsystems. }\end{array}$ & $\begin{array}{l}\text { Environmental risks are } \\
\text { highlighted by the ES } \\
\text { community as an } \\
\text { agenda-setter. This is } \\
\text { particularly true of the } \\
\text { science-policy and } \\
\text { economic approaches. }\end{array}$ & $\begin{array}{l}\text { The ES framework and the } \\
\text { ES demand are also socially } \\
\text { constructed. }\end{array}$ \\
\hline
\end{tabular}


Table 1. Cont.

\begin{tabular}{|c|c|c|c|}
\hline & Systems Theory & $\begin{array}{l}\text { Second Modernity } \\
\text { (World Risk Society) }\end{array}$ & Cultural Theory of Risk \\
\hline $\begin{array}{l}\text { Lessons for ES } \\
\text { framework }\end{array}$ & $\begin{array}{l}\text { The complexity of society, with } \\
\text { different social subsystems } \\
\text { and orientations, must be } \\
\text { integrated into the ES } \\
\text { framework (macro-level). }\end{array}$ & $\begin{array}{l}\text { Offers an approach to } \\
\text { characterizing society and } \\
\text { its development. Trends } \\
\text { such as globalization, } \\
\text { individualization, and } \\
\text { changes to socio-cultural } \\
\text { risk perception offer a new } \\
\text { perspective on ES demand } \\
\text { (macro-/micro-level). }\end{array}$ & $\begin{array}{l}\text { The socio-cultural } \\
\text { dimensions must be } \\
\text { addressed in an ES approach } \\
\text { in order to understand ES } \\
\text { demand and risk perception } \\
\text { at the individual level. The } \\
\text { Grid-Group typology allows } \\
\text { for systematic assessment } \\
\text { (micro-level). }\end{array}$ \\
\hline
\end{tabular}

\section{Discussion and Outlook}

Multi-, inter-, and transdisciplinary research on the ES framework has been evolving for decades [5,32]. Here, I have shown from the perspective of sociological risk theory that these developments are not detached from the 'Zeitgeist'. As long as 40 years ago, it was recognized that technological developments, over-consumption of material resources, and the neoliberal economic model caused negative side effects on nature. In addition, a new dimension of risk was identified that respects neither geographic borders, time horizons, nor class divisions in society. As a consequence, scientific models of thought were sought to gain a better understanding of the relationship between nature and society. Despite variation in ES approaches, their overall depiction of the relationship between humans and nature is largely consistent and internationally recognized, thus allowing ES science to act as an agenda-setter on a global level and communicate its knowledge to other social subsystems. However, the influence of risk is best integrated into the SES approach at the real, measurable level (e.g., detailing how regulating ES or climate adaptation services contribute to risk mitigation [10]). The perspective of sociological risk theory emphasizes the importance of understanding which environmental risks are perceived by society and individuals and how risk affects their ES demand. This section summarizes the findings of this review into sociological risk theory and its implications for ES, and sets out directions for future social risk investigations within ES research.

Research based on the SES approach already provides initial insights into the ES supply-demand relationship. Studies collect data to determine people's ES preferences and, thus, their ES demand and how it is influenced by/related to nature. These data can be related to socio-demographic data, e.g., in attempts to identify the factors influencing ES demand like gender, age, or belonging to an interest group (see also $[28,31,64,131]$ ). However, the querying of preferences is not enough to understand and resolve possible mismatches between supply and demand or socio-culturally driven conflicts between interest groups. For example, if agriculture is the dominant sector in a region, and the management preferences and ES use of farmers are both completely unsustainable and detrimental to other interest groups, then this constitutes a risk. Understanding how farmers and others perceive this risk is necessary if solutions are to be found. Here, a constructivist perspective of risk theory can contribute, as it considers the immaterial dimension of ES demand and the temporal as well as spatial dynamics of ES supply and demand. To continue the agricultural example, a technical risk assessment of agricultural impacts could be compared to the findings about perceived risks. This could explain environmental mismanagement and help identify means of communicating solutions within the specific social system. For example, economic risk could prevent a farmer from managing their farm with organic certification. By doing so, the farmer places economic risks above long-term ecological risks. This is where the educational work of the ES research community can start.

Next, I would like to focus on three key insights with regard to the demand-side of the ES framework: (1) A deeper understanding of societal structures within the social-ecological system helps understand culturally driven patterns of ES demand as well as risk perception and to embed the social system and individuals into the ES framework; (2) sociological ES research should use inter- and transdisciplinary research methods to understand the drivers of ES demand and risk perception, and 
link this understanding to natural science knowledge of the drivers of ES supply if it is to open up new communication and regulatory strategies; (3) while anthropocentric in character, the ES framework, especially one that is modified by the sociological concept of risk, enables society to reflect on its role as a potentially proactive part of a social-ecological system, rather than a passive victim of nature's whims. Figure 5 summarizes the knowledge that needs to be acquired.

A key insight of this review is that the incorporation of sociological risk theory into the ES framework should lead to a more detailed picture of the complex social system at both the micro(individuals) and macro-scales (social subsystems within a social network). This extension is readily compatible with the SES approach, as it already considers both of these scales in ES research. Furthermore, the SES approach recognizes that the macro-level consists of a multi-level system of society (e.g., by examining how governance influences local land use by several social subsystems). Furthermore, the importance of integrating the temporal and spatial dynamics in the analysis is integrated in several SES studies $[27,45,67,92,132]$. In a theoretical framework that combines sociological risk theory and the SES approach, several questions can be addressed that relate to the relationship between ES demand, risk perception, and socio-cultural factors. As a starting point, one may hypothesize that ES demand is driven by traditional, local values and cultural norms. However, these may be further shaped by detraditionalization and globalization. Future ES research could therefore investigate the effects of globalization or regionalization on ES demand and risk perception. We may also hypothesize that ES demand and knowledge about risks are socially constructed on the macro-level through social changes, but also on the micro-level through our individual environment. An in-depth analysis of such socio-cultural dynamics can be used to help develop a communication strategy between subsystems, and research results could be used to generate irritations, e.g., by applying mixed social science methods combining both qualitative and quantitative methods, such as interviews and surveys, and showing these results to stakeholders to foster understanding and communication between groups.

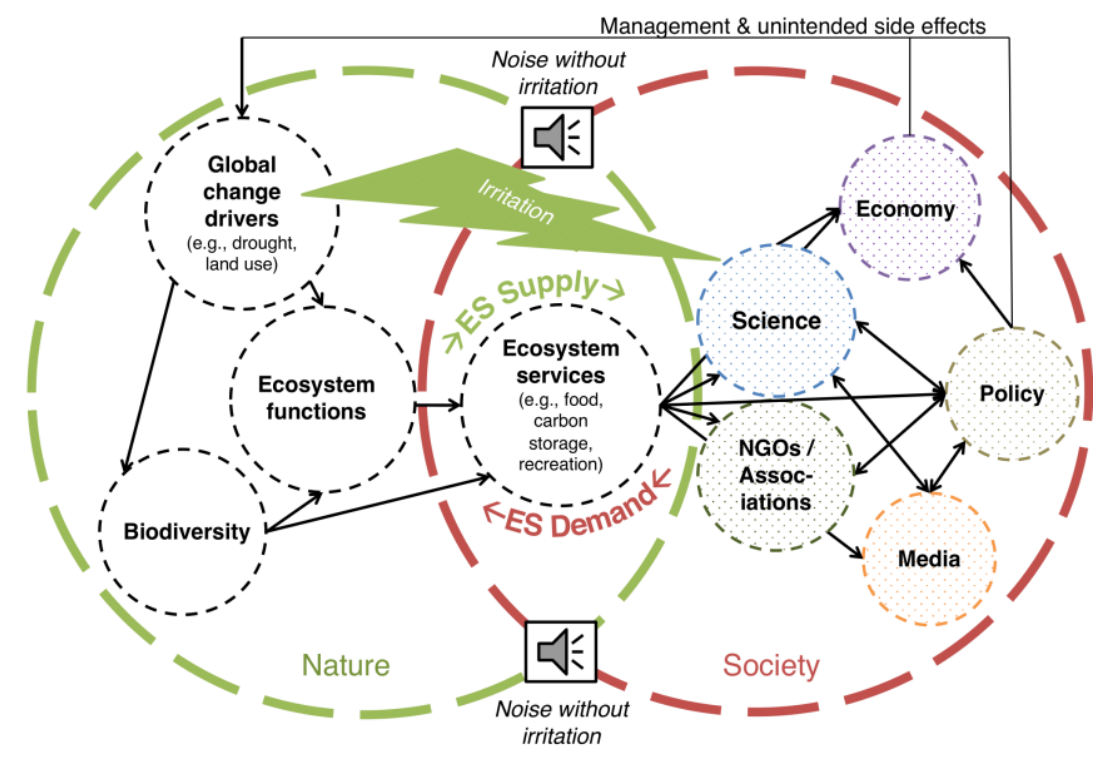

Figure 5. Integration of the results from the perspective of sociological theory of risk into the existing ES framework. For simplicity, only a subset of social subsystems and linkages between components of the social-ecological system are shown.

The causes and consequences of biodiversity loss and other forms of environmental degradation have been globally identified by scientific research (Figure 5). However, currently, for many, biodiversity loss or climate change and their consequences are not yet noticeable and can be described as a 'noise'. Such framing explains why society often does little to address environmental risks, and why the ES demand and use often do not change. As Beck correctly explains, social reflexivity does not have to 
lead to individual reflection, because risk is perceived differently between individuals and groups. For the farmer, the loss of biodiversity is a yield risk; for the locals, a loss of regional identity. Renn [23] describes these differences in perception with his risk paradox. Here, perception and evaluation result in a plural society [133]. This plurality takes place at both the societal level in the division into ES interest groups, but also within each interest group. The cultural theory of risk provides a starting point to describe these groups with its Grid-Group typology (Figure 4). It should also be noted that, while members of an established interest group, like agriculture or forestry, may have the same ES demand, this may be driven by different motives (e.g., forests shape the landscape and regional identity, while for others, it is a source of financial income). Furthermore, they may belong to one interest group, but have completely different views from those of others of the same group on how to deal with risk, or what constitutes risk. To conclude, integrated consideration of a plural society can lead to a better and sustainable understanding of ES demand and risk perception in future ES research.

A second key insight of this perspective is that it is not always possible to control supply, but it is possible for researchers to actively engage with stakeholders. This may shape their ES demand and risk perception, potentially reducing conflict and leading to more sustainable behavior. One example of operationalizing social risk in ES research is to question individuals about their ES preferences, but also their cultural conditions and risk perceptions. Such research can take place on the two levels identified by Luhmann: The first observation, which involves a quantitative assessment of real risks, and the second, an observation of risk perception by social science approaches. This may be achieved by first conducting a participatory social network analysis to gain insights about the specific social system and its subsystems. Next, qualitative interviews could be arranged in order to capture individual perceptions within the social subsystems (e.g., questions about what motivates human patterns of ES demand within the context of socio-cultural dynamics and risks). While interviews can be used for detailed findings, quantitative surveys offer the opportunity to verify these findings in a representative manner. Such research can also enable the application of the Grid-Group typology with the query of statements. Subsequently, natural scientific results about real risk can be combined with social science findings about perceived risk to reveal discrepancies and possible causes of mismanagement. The knowledge gained from doing this can be used to identify ways of minimizing risks and promoting sustainable development. Systems theory may also be employed where communication between the social subsystems using the economic ES approach is limited. From this theoretical consideration, communication within the ES community, but also with wider society, must be tailored to the binary code of the different social subsystems. Additionally, empirical social science research can employ the sociological risk theory presented here to help identify regulatory instruments that reduce conflict and minimize risk, e.g., by providing positive incentives (e.g., money, respect, sense of belonging) and to promote the care of nature.

Finally, while the ES framework provides a range of benefits, its anthropocentric character must be critically considered. The ES framework is built upon an eco-centric concept of nature conservation to shift the focus onto human actions with negative consequences for humanity. However, the position that nature and society are equals, which is shown in the SES approach, must be critically reflected upon. Systems theory makes it clear that nature cannot be an equal counterpart to society for the simple reason that ecosystems cannot communicate and negotiate. Likewise, natural events will happen regardless of societal discourse, and so, the environmental risks of global environmental change will become a reality, even if they are not discussed by society. It is therefore up to society to respond proactively, not reactively, to environmental change, to communicate risks, and to reconsider its risk perception. This focus on the human being as a responsible actor within the SES gives individuals the empowerment to change their patterns of ES demand and, hence, their interaction with nature, as Beck emphasizes. Future research could also investigate the level of risk deemed acceptable by society and the degree of system resilience required to keep risk within the socially accepted level. In summary, the ES framework can be applied as a tool box, which can be used to create a common, systematic understanding of the whole range of the society-nature relationships. In this way, the 
interaction between ES supply and demand and the influencing social perception of risk can be better investigated in future ES research. By discussing the three sociological risk theories, research questions can be posed on the societal and individual levels. The gained knowledge can also be used to identify ways in which to mitigate and adapt to environmental risks. In turn, this knowledge may be used to develop regulating instruments that promote sustainable development.

Funding: This research was funded by Senckenberg Society for Nature Resesarch/Senckenberg Biodiversität und Klima- Forschungszentrum (SBiK-F).

Acknowledgments: I would like to thank Peter Manning (SBiK-F), Birgit Blättel-Mink (Department of Social Sciences at Goethe University), Marion Mehring (ISOE), and Thomas Müller (SBiK-F) for their support during the writing process. The PhD is part of the DFG-funded research project "Biodiversity Exploratories" and the junior research group "Causes and Consequences of Biodiversity Change". Furthermore, I would like to thank those involved for the stimulating discussion at the ESP 10 meeting in Hannover.

Conflicts of Interest: The author declares no conflict of interest.

\section{References}

1. Carson, R.; Darling, L. Silent Spring; Houghton Mifflin: Boston, MA, USA; Riverside Press: Cambridge, MA, USA, 1967.

2. Meadows, D.H. Limits to Growth; New American Library: New York, NY, USA, 1972.

3. Daily, G.C. Nature's Services: Societal Dependence on Natural Ecosystems; Island Press: Washington, DC, USA, 1997.

4. Mace, G.M.; Norris, K.; Fitter, A.H. Biodiversity and ecosystem services: A multilayered relationship. Trends Ecol. Evol. 2012, 27, 19-26. [CrossRef] [PubMed]

5. Costanza, R.; de Groot, R.; Braat, L.; Kubiszewski, I.; Fioramonti, L.; Sutton, P.; Farber, S.; Grasso, M. Twenty years of ecosystem services: How far have we come and how far do we still need to go? Ecosyst. Serv. 2017, 28, 1-16. [CrossRef]

6. Millennium Ecosystem Assessment. Ecosystems and Human Well-being: Synthesis; Island Press: Washington, DC, USA, 2005.

7. Haines-Young, R.H.; Potschin, M.B. Common International Classification of Ecosystem Services (CICES) V5.1 and Guidance on the Application of the Revised Structure; Fabis Consulting Ltd.: Nottingham, UK, 2018.

8. Pascual, U.; Balvanera, P.; Díaz, S.; Pataki, G.; Roth, E.; Stenseke, M.; Watson, R.T.; Başak Dessane, E.; Islar, M.; Kelemen, E.; et al. Valuing nature's contributions to people: The IPBES approach. Curr. Opin. Environ. Sustain. 2017, 26-27, 7-16. [CrossRef]

9. Renn, O.; Schweizer, P.-J.; Dreyer, M.; Klinke, A. Risiko. Über den Gesellschaftlichen Umgang mit Unsicherheit; Oekom-Verlag: München, Germany, 2007.

10. Lavorel, S.; Colloff, M.J.; McIntyre, S.; Doherty, M.D.; Murphy, H.T.; Metcalfe, D.J.; Dunlop, M.; Williams, R.J.; Wise, R.M.; Williams, K.J. Ecological mechanisms underpinning climate adaptation services. Glob. Chang. Biol. 2015, 21, 12-31. [CrossRef]

11. Lavorel, S.; Locatelli, B.; Colloff, M.J.; Bruley, E. Co-producing ecosystem services for adapting to climate change. Philos. Trans. R. Soc. Lond. B Biol. Sci. 2020, 375, 20190119. [CrossRef]

12. Bartkowski, B.; Hansjürgens, B. Risk and uncertainty as sources of economic value of biodiversity and ecosystem services. In Atlas of Ecosystem Services; Schröter, M., Bonn, A., Klotz, S., Seppelt, R., Baessler, C., Eds.; Springer International Publishing: Cham, Switzerland, 2019; pp. 21-24.

13. Cornell, J.D.; Quintas-Soriano, C.; Running, K.; Castro, A.J. Examining concern about climate change and local environmental changes from an ecosystem service perspective in the western U.S. Environ. Sci. Policy 2019, 101, 221-231. [CrossRef]

14. Beck, U. Risikogesellschaft-Auf dem Weg in eine andere Moderne; Suhrkamp Verlag: Frankfurt am Main, Germany, 1986.

15. Zinn, J.O. A comparison of sociological theorizing on risk and uncertainty. In Social Theories of Risk and Uncertainty: An Introduction; Zinn, J.O., Ed.; Blackwell Publishing Ltd.: Oxford, UK, 2008; pp. 168-210.

16. O'Malley, P. Governmentality and risk. In Social Theories of Risk and Uncertainty; Zinn, J.O., Ed.; Blackwell Publishing Ltd.: Oxford, UK, 2008.

17. Potschin, M.B.; Haines-Young, R.H. From nature to society. In Mapping Ecosystem Services; Burkhard, B., Maes, J., Eds.; Pensoft Publishers: Sofia, Bulgaria, 2017. 
18. Allan, E.; Manning, P.; Alt, F.; Binkenstein, J.; Blaser, S.; Bluthgen, N.; Bohm, S.; Grassein, F.; Holzel, N.; Klaus, V.H.; et al. Land use intensification alters ecosystem multifunctionality via loss of biodiversity and changes to functional composition. Ecol. Lett. 2015, 18, 834-843. [CrossRef]

19. Diaz, S.; Settele, J.; Brondizio, E.; Ngo, H.T.; Guèze, M.; Agard, J.; Arneth, A.; Balvanera, P.; Brauman, K.A.; Butchart, S.; et al. Summary for Policymakers of the Global Assessment Report on Biodiversity and Ecosystem Services of the Intergovernmental Science-Policy Platform on Biodiversity and Ecosystem Services; IPBES Secretariat: Bonn, Germany, 2019.

20. Luhmann, N. Ökologische Kommunikation: Kann die Moderne Gesellschaft sich auf Ökologische Gefährdungen Einstellen? Westdeutscher Verlag: Opladen, Germany, 1986.

21. WEF. The Global Risks Report 2020; World Economic Forum: Geneva, Switzerland, 2020.

22. Zinn, J.O. Introduction: The contribution of sociology to the discourse on risk and uncertainty. In Social Theories of Risk and Uncertainty: An Introduction; Zinn, J.O., Ed.; Blackwell Publishing Ltd.: Oxford, UK, 2008; pp. 1-17.

23. Renn, O. Das Risikoparadox. Warum wir uns vor dem Falschen fürchten; Fischer Taschenbuch Verlag: Berlin, Germany, 2014.

24. Crouzat, E.; Martín-López, B.; Turkelboom, F.; Lavorel, S. Disentangling trade-offs and synergies around ecosystem services with the influence network framework: Illustration from a consultative process over the French Alps. Ecol. Soc. 2016, 21, 32. [CrossRef]

25. Douglas, M. Natural Symbols: Explorations in Cosmology; Barrie \& Rockliff, Cresset Press: London, UK, 1970.

26. Abson, D.J.; von Wehrden, H.; Baumgärtner, S.; Fischer, J.; Hanspach, J.; Härdtle, W.; Heinrichs, H.; Klein, A.M.; Lang, D.J.; Martens, P.; et al. Ecosystem services as a boundary object for sustainability. Ecol. Econ. 2014, 103, 29-37. [CrossRef]

27. Felipe-Lucia, M.R.; Comin, F.A.; Escalera-Reyes, J. A framework for the social valuation of ecosystem services. Ambio 2015, 44, 308-318. [CrossRef]

28. Felipe-Lucia, M.R.; Martin-Lopez, B.; Lavorel, S.; Berraquero-Diaz, L.; Escalera-Reyes, J.; Comin, F.A. Ecosystem services flows: Why stakeholders' power relationships matter. PLoS ONE 2015, 10, e0132232. [CrossRef] [PubMed]

29. Schröter, M.; van der Zanden, E.H.; van Oudenhoven, A.P.E.; Remme, R.P.; Serna-Chavez, H.M.; de Groot, R.S.; Opdam, P. Ecosystem services as a contested concept: A synthesis of critique and counter-arguments. Conserv. Lett. 2014, 7, 514-523. [CrossRef]

30. Brand, K.-W. Soziologie und Natur-eine schwierige Beziehung. Zur Einführung. In Soziologie und Natur. Theoretische Perspektiven; Brand, K.-W., Ed.; Springer Fachmedien: Wiesbaden, Germany, 1998.

31. Castro, A.J.; Vaughn, C.C.; Julian, J.P.; García-Llorente, M. Social demand for ecosystem services and implications for watershed management. Jawra J. Am. Water Resour. Assoc. 2015, 52, 209-221. [CrossRef]

32. De Groot, R.; Braat, L.; Costanza, R. A short history of the ecosystem services concept. In Mapping Ecosystem Services; Burkhard, B., Maes, J., Eds.; Pensoft Publishers: Sofia, Bulgaria, 2017.

33. Iniesta-Arandia, I.; Garcia-Llorente, M.; Aguilera, P.A.; Montes, C.; Martin-Lopez, B. Socio-cultural valuation of ecosystem services: Uncovering the links between values, drivers of change, and human well-being. Ecol. Econ. 2014, 108, 36-48. [CrossRef]

34. Potschin-Young, M.; Haines-Young, R.H.; Görg, C.; Heink, U.; Jax, K.; Schleyer, C. Understanding the role of conceptual frameworks: Reading the ecosystem services cascade. Ecosyst. Serv. 2018, 29, 428-440. [CrossRef]

35. Manning, P.; van der Plas, F.; Soliveres, S.; Allan, E.; Maestre, F.T.; Mace, G.; Whittingham, M.J.; Fischer, M. Redefining ecosystem multifunctionality. Nat. Ecol. Evol. 2018, 2, 427-436. [CrossRef]

36. Potschin, M.B.; Haines-Young, R.H. Ecosystem services. Prog. Phys. Geogr. 2011, 35, 575-594. [CrossRef]

37. Potschin, M.B.; Haines-Young, R.H. Defining and measuring ecosystem services. In Handbook of Ecosystem Services; Potschin, M.B., Haines-Young, R.H., Fish, R., Turner, R.K., Eds.; Routledge: London, UK; New York, NY, USA, 2016; pp. 25-44.

38. Diaz, S.; Lavorel, S.; de Bello, F.; Quetier, F.; Grigulis, K.; Robson, T.M. Incorporating plant functional diversity effects in ecosystem service assessments. Proc. Natl. Acad. Sci. USA 2007, 104, 20684-20689. [CrossRef]

39. Hauck, J.; Görg, C.; Varjopuro, R.; Ratamäki, O.; Jax, K. Benefits and limitations of the ecosystem services concept in environmental policy and decision making: Some stakeholder perspectives. Environ. Sci. Policy 2013, 25, 13-21. [CrossRef] 
40. Spierenburg, M. Getting the message across biodiversity science and policy interfaces-A review. Gaia Ecol. Perspect. Sci. Soc. 2012, 21, 125-134. [CrossRef]

41. Wei, H.; Fan, W.; Wang, X.; Lu, N.; Dong, X.; Zhao, Y.; Ya, X.; Zhao, Y. Integrating supply and social demand in ecosystem services assessment: A review. Ecosyst. Serv. 2017, 25, 15-27. [CrossRef]

42. Costanza, R.; d'Arge, R.; de Groot, R.; Farber, S.; Grasso, M.; Hannon, B.; Limburg, K.; Naeem, S.; O’Neill, R.V.; Paruelo, J.; et al. The value of the world's ecosystem services and natural capital. Nature 1997, 387, 253-260. [CrossRef]

43. Lele, S.; Springate-Baginski, O.; Lakerveld, R.; Deb, D.; Dash, P. Ecosystem services: Origins, contributions, pitfalls, and alternatives. Conserv. Soc. 2013, 11, 343-358. [CrossRef]

44. TEEB. The Initiative. Available online: http://www.teebweb.org/about/the-initiative/ (accessed on 11 December 2019).

45. Schleyer, C.; Lux, A.; Mehring, M.; Görg, C. Ecosystem services as a boundary concept: Arguments from social ecology. Sustainability 2017, 9, 1107. [CrossRef]

46. Droste, N.; D'Amato, D.; Goddard, J.J. Where communities intermingle, diversity grows-The evolution of topics in ecosystem service research. PLoS ONE 2018, 13, e0204749. [CrossRef]

47. Jetzkowitz, J. Ökosystemdienstleistungen in soziologischer Perspektive. In Handbuch Umweltsoziologie; Groß, M., Ed.; Springer: Wiesbaden, Germany, 2011; pp. 303-324.

48. Diaz, S.; Pascual, U.; Stenseke, M.; Martin-Lopez, B.; Watson, R.T.; Molnar, Z.; Hill, R.; Chan, K.M.A.; Baste, I.A.; Brauman, K.A.; et al. Assessing nature's contributions to people. Science 2018, 359, $270-272$. [CrossRef]

49. Timpte, M.; Montana, J.; Reuter, K.; Borie, M.; Apkes, J. Engaging diverse experts in a global environmental assessment: Participation in the first work programme of IPBES and opportunities for improvement. Innov. Eur. J. Soc. Sci. Res. 2018, 31, S15-S37. [CrossRef]

50. Mehring, M.; Bernard, B.; Hummel, D.; Liehr, S.; Lux, A. Halting biodiversity loss: How social-ecological biodiversity research makes a difference. Int. J. Biodivers. Sci. Ecosyst. Serv. Manag. 2017, 13, 172-180. [CrossRef]

51. Balvanera, P.; Daw, T.M.; Gardner, T.A.; Martín-López, B.; Norström, A.V.; Ifejika Speranza, C.; Spierenburg, M.; Bennett, E.M.; Farfan, M.; Hamann, M.; et al. Key features for more successful place-based sustainability research on social-ecological systems: A programme on ecosystem change and society (pecs) perspective. Ecol. Soc. 2017, 22, 14. [CrossRef]

52. Balvanera, P.; Calderón-Contreras, R.; Castro, A.J.; Felipe-Lucia, M.R.; Geijzendorffer, I.R.; Jacobs, S.; Martín-López, B.; Arbieu, U.; Speranza, C.I.; Locatelli, B.; et al. Interconnected place-based social-ecological research can inform global sustainability. Curr. Opin. Environ. Sustain. 2017, 29, 1-7. [CrossRef]

53. Reyers, B.; Biggs, R.; Cumming, G.S.; Elmqvist, T.; Hejnowicz, A.P.; Polasky, S. Getting the measure of ecosystem services: A social-ecological approach. Front. Ecol. Environ. 2013, 11, 268-273. [CrossRef]

54. Reyers, B.; Folke, C.; Moore, M.-L.; Biggs, R.; Galaz, V. Social-ecological systems insights for navigating the dynamics of the anthropocene. Annu. Rev. Environ. Resour. 2018, 43, 267-289. [CrossRef]

55. Schlüter, M.; Haider, L.J.; Lade, S.J.; Lindkvist, E.; Martin, R.; Orach, K.; Wijermans, N.; Folke, C. Capturing emergent phenomena in social-ecological systems: An analytical framework. Ecol. Soc. 2019, $24,11$. [CrossRef]

56. Steger, C.; Hirsch, S.; Evers, C.; Branoff, B.; Petrova, M.; Nielsen-Pincus, M.; Wardropper, C.; van Riper, C.J. Ecosystem services as boundary objects for transdisciplinary collaboration. Ecol. Econ. 2018, 143, 153-160. [CrossRef]

57. van Oudenhoven, A.P.E.; Martín-López, B.; Schröter, M.; de Groot, R. Advancing science on the multiple connections between biodiversity, ecosystems and people. Int. J. Biodivers. Sci. Ecosyst. Serv. Manag. 2018, 14, 127-131. [CrossRef]

58. Binder, C.R.; Hinkel, J.; Bots, P.W.G.; Pahl-Wostl, C. Comparison of frameworks for analyzing social-ecological systems. Ecol. Soc. 2013, 18, 26. [CrossRef]

59. Cumming, G.S. Theoretical frameworks for the analysis of social-ecological systems. In Social-Ecological Systems in Transition, Global Environmental Studies; Sakai, S., Umetsu, C., Eds.; Springer: Tokyo, Japan, 2014; pp. 3-24.

60. García-Llorente, M.; Iniesta-Arandia, I.; Willaarts, B.A.; Harrison, P.A.; Berry, P.; Bayo, M.d.M.; Castro, A.J.; Montes, C.; Martín-López, B. Biophysical and sociocultural factors underlying spatial trade-offs of ecosystem services in semiarid watersheds. Ecol. Soc. 2015, 20, 39. [CrossRef] 
61. Martín-López, B.; Gómez-Baggethun, E.; García-Llorente, M.; Montes, C. Trade-offs across value-domains in ecosystem services assessment. Ecol. Indic. 2014, 37, 220-228. [CrossRef]

62. Oteros-Rozas, E.; Martín-López, B.; González, J.A.; Plieninger, T.; López, C.A.; Montes, C. Socio-cultural valuation of ecosystem services in a transhumance social-ecological network. Reg. Environ. Chang. 2013, 14, 1269-1289. [CrossRef]

63. Quintas-Soriano, C.; Brandt, J.S.; Running, K.; Baxter, C.V.; Gibson, D.M.; Narducci, J.; Castro, A.J. Social-ecological systems influence ecosystem service perception: A programme on ecosystem change and society (PECS) analysis. Ecol. Soc. 2018, 23, 3. [CrossRef]

64. Wolff, S.; Schulp, C.J.E.; Verburg, P.H. Mapping ecosystem services demand: A review of current research and future perspectives. Ecol. Indic. 2015, 55, 159-171. [CrossRef]

65. Becker, E.; Jahn, T. Soziale Ökologie. Grundzüge einer Wissenschaft von den Gesellschaftlichen Naturverhältnissen; Campus: Frankfurt, Germany; New York, NY, USA, 2006.

66. Liehr, S.; Röhrig, J.; Mehring, M.; Kluge, T. How the social-ecological systems concept can guide transdisciplinary research and implementation: Addressing water challenges in central northern Namibia. Sustainability 2017, 9, 1109. [CrossRef]

67. Mehring, M.; Zajonz, U.; Hummel, D. Social-ecological dynamics of ecosystem services: Livelihoods and the functional relation between ecosystem service supply and demand-Evidence from Socotra archipelago, Yemen and the Sahel region, West Africa. Sustainability 2017, 9, 1037. [CrossRef]

68. Tauro, A.; Gómez-Baggethun, E.; García-Frapolli, E.; Lazos Chavero, E.; Balvanera, P. Unraveling heterogeneity in the importance of ecosystem services: Individual views of smallholders. Ecol. Soc. 2018, 23, 11. [CrossRef]

69. García-Nieto, A.P.; García-Llorente, M.; Iniesta-Arandia, I.; Martín-López, B. Mapping forest ecosystem services: From providing units to beneficiaries. Ecosyst. Serv. 2013, 4, 126-138. [CrossRef]

70. Schmidt, K.; Walz, A.; Martin-Lopez, B.; Sachse, R. Testing socio-cultural valuation methods of ecosystem services to explain land use preferences. Ecosyst Serv. 2017, 26, 270-288. [CrossRef]

71. Castro, A.J.; Martín-López, B.; López, E.; Plieninger, T.; Alcaraz-Segura, D.; Vaughn, C.C.; Cabello, J. Do protected areas networks ensure the supply of ecosystem services? Spatial patterns of two nature reserve systems in semi-arid spain. Appl. Geogr. 2015, 60,1-9. [CrossRef]

72. Bennett, E.M.; Peterson, G.D.; Gordon, L.J. Understanding relationships among multiple ecosystem services. Ecol. Lett. 2009, 12, 1394-1404. [CrossRef]

73. Barnaud, C.; Corbera, E.; Muradian, R.; Salliou, N.; Sirami, C.; Vialatte, A.; Choisis, J.-P.; Dendoncker, N.; Mathevet, R.; Moreau, C.; et al. Ecosystem services, social interdependencies, and collective action: A conceptual framework. Ecol. Soc. 2018, 23, 15. [CrossRef]

74. García-Llorente, M.; Martín-López, B.; Iniesta-Arandia, I.; López-Santiago, C.A.; Aguilera, P.A.; Montes, C. The role of multi-functionality in social preferences toward semi-arid rural landscapes: An ecosystem service approach. Environ. Sci. Policy 2012, 19-20, 136-146.

75. Zinn, J.O. Literature Review: Sociology and Risk; Social Contexts and Responses to Risk Network (SCARR); School of Social Policy, Sociology and Social Research (SSPSSR): Canterbury, UK, 2004; Volume 4.

76. Zinn, J.O. Recent developments in sociology of risk and uncertainty. Hist. Soc. Res. 2006, 31, $275-286$.

77. Zinn, J.O. The meaning of risk-taking-Key concepts and dimensions. J. Risk Res. 2017, 22, 1-15. [CrossRef]

78. Japp, K.P.; Kusche, I. Systems theory and risk. In Social Theories of Risk and Uncertainty. An Introduction; Zinn, J.O., Ed.; Blackwell Publishing Ltd.: Oxford, UK, 2008.

79. Luhmann, N. Ecological Communication; The University of Chicaco Press: Chicago, IL, USA, 1989.

80. Luhmann, N. Ökologie des Nichtwissens. In Beobachtungen der Moderne; Westdeutscher Verlag: Opladen, Germany, 1992; pp. 149-220.

81. Luhmann, N. Operational closure and structural coupling: The differentiation of the legal system. Cardozo Law Rev. 1992, 13, 1419-1441.

82. Kühne, O. Das Konzept der Ökosystemdienstleistungen als Ausdruck ökologischer Kommunikation. Nat. Landsch. 2014, 46, 017-022.

83. Reese-Schäfer, W. Niklas Luhmann zur Einführung; Junius Verlag GmbH: Hamburg, Germany, 1999.

84. Cardinale, B.J.; Duffy, J.E.; Gonzalez, A.; Hooper, D.U.; Perrings, C.; Venail, P.; Narwani, A.; Mace, G.M.; Tilman, D.; Wardle, D.A.; et al. Biodiversity loss and its impact on humanity. Nature 2012, 486, 59-67. [CrossRef] 
85. Tilman, D.; Isbell, F.; Cowles, J.M. Biodiversity and ecosystem functioning. Annu. Rev. Ecol. Evol. Syst. 2014, 45, 471-493. [CrossRef]

86. Boholm, M. The semantic distinction between "risk" and "danger": A linguistic analysis. Risk Anal. 2012, 32, 281-293. [CrossRef]

87. Luhmann, N. Technology, environment and social risk. A systems perspective. Ind. Crisis 1990, 4, $223-231$. [CrossRef]

88. Luhmann, N. Die gesellschaftliche Verantwortung der Soziologie. In Universität als Milieu; Luhmann, N., Ed.; Kleine Schriften: Bielefeld, Germany, 1992; pp. 126-136.

89. Luhmann, N. Risk: A Sociological Theory/Niklas Luhmann; with a New Introduction by Nico Stehr and Gotthard Bechmann; Routledge: New York, NY, USA, 2005.

90. Luhmann, N. Die Autopoiesis des Bewusstseins. Soz. Welt 1985, 36, 402-446.

91. Treibel, A. Einführung in soziologische Theorien der Gegenwart; VS Verlag für Sozialwissenschaften: Wiesbaden, Germany, 2006.

92. Mehring, M.; Ott, E.; Hummel, D. Ecosystem services supply and demand assessment: Why social-ecological dynamics matter. Ecosyst. Serv. 2018, 30, 124-125. [CrossRef]

93. Mattheis, C. The system theory of Niklas Luhmann and the constitutionalization of the world society. J. Int. Law 2012, 4, 625-647.

94. Beck, U. Risk Society: Towards a New Modernity; (Published in Association with Theory, Culture E Society) (Theory, Culture, and Society Series); SAGE Publications Ltd.: London, UK; New York, NY, USA, 1992.

95. Beck, U. World at Risk; Polity: Cambridge, UK, 2008.

96. Beck, U. Pioneer in Cosmopolitan Sociology and Risk Society; Springer: London, UK, 2014.

97. Rasborg, K. '(World) risk society' or 'new rationalities of risk'? A critical discussion of Ulrich Beck's theory of reflexive modernity. Thesis Elev. 2012, 108, 3-25. [CrossRef]

98. Zinn, J.O. Risk society and reflexive modernization. In Social Theories of Risk and Incertainty. An Introduction; Zinn, J.O., Ed.; Blackwell Publishing Ltd.: Oxford, UK, 2008; pp. 18-51.

99. Taylor-Gooby, P.; Zinn, J. Current Directions in Risk Research Reinvigorating the Social; Social Contexts and Responses to Risk Network (SCARR); School of Social Policy, Sociology and Social Research (SSPSSR): Canterbury, UK, 2005.

100. Grundmann, R. Wo steht die Risikosoziologie? Zeitschrift Für Soziologie 1999, 28, 44-59. [CrossRef]

101. Lyng, S. Edgework, Risk, and Uncertainty. In Social Theories of Risk and Uncertainty; Zinn, J.O., Ed.; Blackwell Publishing Ltd.: Oxford, UK, 2008.

102. Cumming, G.S.; Buerkert, A.; Hoffmann, E.M.; Schlecht, E.; von Cramon-Taubadel, S.; Tscharntke, T. Implications of agricultural transitions and urbanization for ecosystem services. Nature 2014, 515, 50-57. [CrossRef] [PubMed]

103. Cumming, G.S.; von Cramon-Taubadel, S. Linking economic growth pathways and environmental sustainability by understanding development as alternate social-ecological regimes. Proc. Natl. Acad. Sci. USA 2018, 115, 9533-9538. [CrossRef] [PubMed]

104. Beck, U.; Holzer, B. Organizations in world risk society. In International Handbook of Organizational Crisis Management; Pearson, C., Roux-Dufort, C., Clair, J., Eds.; Sage: London, UK, 2007; Volume 3-4.

105. Beck, U.; Beck-Gernsheim, E. Individualization. Institutionalized Individualism and its Social and Political Consequences; SAGE Publications: London, UK, 2002.

106. Beck, U.; Beck-Gernsheim, E. Individualisierung in modernen Gesellschaften-Perspektiven und Kontroversen einer subjektorientierten Soziologie. In Riskante Freiheiten. Individualisierung in Modernen Gesellschaften; Beck, U., Beck-Gernsheim, E., Eds.; Suhrkamp: Frankfurt am Main, Germany, 1994; pp. 10-39.

107. Beck, U. What is Globalization? Polity Press: Cambridge, UK, 2000.

108. Adam, B. The Risk Society and Beyond: Critial Issues for Social Theory; SAGE Publications: London, UK, 2000.

109. Tulloch, J. Culture and risk. In Social Theories of Risk and Uncertainty; Zinn, J.O., Ed.; Blackwell Publishing Ltd.: Oxford, UK, 2008.

110. Douglas, M.; Wildavsky, A.B. Risk and Culture: An. Essay on the Selection of Technical and Environmental Dangers; University of California Press: Berkeley, CA, USA, 1982.

111. Rippl, S. Cultural theory and risk perception: A proposal for a better measurement. J. Risk Res. 2002, 5, 147-165. [CrossRef] 
112. Douglas, M. A History of Grid and Group Cultural Theory. Available online: http://projects.chass.utoronto. ca/semiotics/cyber/douglas1.pdf (accessed on 6 December 2019).

113. Lidskog, R.; Sundqvist, G. Sociology of risk. In Handbook of Risk Theory: Epistemology, Decision Theory, Ethis, and Social Implications of Risk; Roeser, S.H.R., Sandin, P., Peterson, M., Eds.; Springer: Dordrecht, The Netherlands; Heidelberg, Germany; London, UK; New York, NY, USA, 2012.

114. Taylor-Gooby, P.; Zinn, J. (Eds.) The current significance of risk. In Risk in Social Science; Oxford University Press: Oxford, UK, 2006.

115. Thompson, M.; Ellis, R.; Wildavsky, A.B. Cultural Theory; Westview Press: Boulder, CO, USA, 1990.

116. Oltedal, S.; Moen, B.-E.; Klempe, H.; Rundmo, T. Explaining Risk Perception: An Evaluation of Cultural Theory; 85th ed.; Department of Psychology, Norwegian University of Science and Technology: Trondheim, Norway, 2004.

117. Tansey, J.; O’Riordan, T. Cultural theory and risk: A review. Healthrisk Soc. 1999, 1, 71-90. [CrossRef]

118. Tulloch, J.; Lupton, D. Risk and Everyday Life; SAGE: London, UK, 2003.

119. Renn, O. Concepts of risk: An interdisciplinary review. Part 1: Disciplinary risk concepts. Gaia Ecol. Perspect. Sci. Soc. 2008, 17, 50-66. [CrossRef]

120. Fragouli, E.; Theodoulou, P. The way people and societies perceive the nature and context of risk is different, due to psychological and cultural issues. J. Econ. Bus. 2015, XVIII, 29-46.

121. Price, J.C.; Walker, I.A.; Boschetti, F. Measuring cultural values and beliefs about environment to identify their role in climate change responses. J. Environ. Psychol. 2014, 37, 8-20. [CrossRef]

122. Douglas, M. Risk and Blame: Essays in Cultural Theory; Routledge: London, UK, 1992.

123. Sellke, P.; Renn, O. Risiko-Governance in einer komplexen Welt. In Handbuch Umweltsoziologie; Groß, M., Ed.; Springer: Wiesbaden, Germany, 2011; pp. 503-528.

124. Adams, J. Risk; Routledge: London, UK; New York, NY, USA, 1995.

125. Steg, L.; Sievers, I. Cultural theory and individual perceptions of environmental risks. Environ. Behav. 2000, 32, 250-269. [CrossRef]

126. Bellamy, R.; Hulme, M. Beyond the tipping point: Understanding perceptions of abrupt climate change and their implications. Weather. Soc. 2011, 3, 48-60. [CrossRef]

127. Kahan, D.M. Cultural cognition as a conception of the cultural theory of risk. In Handbook of Risk Theory. Epistemology, Decision Theory, Ethics, and Social Implications of Risk; Roeser, S., Hillerbrand, R., Sandin, P., Peterson, M., Eds.; Springer: Berlin, Germany, 2012; pp. 726-753.

128. Lash, S. Risk culture. In The Risk Society and Beyond: Critical Issues for Social Theory; Adam, B., Ed.; SAGE Publications: London, UK, 2000.

129. Wildavsky, A.B.; Dake, K. Theories of Risk Perception: Who Fears What and Why? Daedalus: Cambridge, MA, USA, 1990; Volume 119, pp. 41-60.

130. Dake, K. Orienting dispositions in the perception of risk: An analysis of contemporary worldviews and cultural biases. J. Cross Cult. Psychol. 1991, 22, 61-82. [CrossRef]

131. Martin-Lopez, B.; Iniesta-Arandia, I.; Garcia-Llorente, M.; Palomo, I.; Casado-Arzuaga, I.; Amo, D.G.; Gomez-Baggethun, E.; Oteros-Rozas, E.; Palacios-Agundez, I.; Willaarts, B.; et al. Uncovering ecosystem service bundles through social preferences. PLoS ONE 2012, 7, e38970. [CrossRef]

132. Hein, L.; van Koppen, C.S.A.; van Ierland, E.C.; Leidekker, J. Temporal scales, ecosystem dynamics, stakeholders and the valuation of ecosystems services. Ecosyst. Serv. 2016, 21, 109-119. [CrossRef]

133. Renn, O. Übergreifende Risiken und Unsicherheiten. In Klimawandel in Deutschland. Entwicklung, Folgen, Risiken und Perspektiven; Brasseur, G.P., Jacob, D., Schuck-Zöller, S., Eds.; Springer Spektrum: Berlin/Heidelberg, Germany, 2017; pp. 295-304.

(C) 2020 by the author. Licensee MDPI, Basel, Switzerland. This article is an open access article distributed under the terms and conditions of the Creative Commons Attribution (CC BY) license (http://creativecommons.org/licenses/by/4.0/). 